\title{
COVID-19 Pandemic and Role of Human Saliva as a Testing Biofluid in Point-of-Care Technology
}

\author{
Hiba Hamid ${ }^{1}$ Zohaib Khurshid ${ }^{2}$ Necdet Adanir ${ }^{3} \quad$ Muhammad S. Zafar ${ }^{4,5}$ Sana Zohaib ${ }^{6}$
}

\footnotetext{
${ }^{1}$ Department of Oral Biology, Liaquat College of Medicine and Dentistry, Karachi, Pakistan

${ }^{2}$ Department of Prosthodontics and Dental Implantology, College of Dentistry, King Faisal University, Al Ahsa, Saudi Arabia

${ }^{3}$ Department of Restorative Dentistry, College of Dentistry, King Faisal University, Al Ahsa, Saudi Arabia

${ }^{4}$ Department of Restorative Dentistry, College of Dentistry, Taibah University, Medina Munawara, Saudi Arabia

${ }^{5}$ Department of Dental Materials, Islamic International Dental College, Riphah International University, Islamabad, Pakistan

6 Department of Biomedical Engineering, College of Engineering, King Faisal University, Al Ahsa, Saudi Arabia
}

\begin{abstract}
Address for correspondence Zohaib Khurshid, MRes, MDTFEd, FPFA, BDS, Department of Prosthodontics and Dental Implantology, College of Dentistry, King Faisal University, Al Ahsa 31982, Saudi Arabia (e-mail: drzohaibkhurshid@gmail.com).
\end{abstract}

\begin{abstract}
Novel coronavirus disease 2019 (COVID-19) outbreak has termed as a controllable pandemic, and the entire world has come to a standstill trying to mitigate the disease with health systems. Health care providers, around the globe, are fighting day and night. Currently, rapid testing is taking place with the help of nasopharyngeal, oropharyngeal swab, bronchoalveolar lavage, sputum, urine, and blood. All these approaches

Keywords

- saliva

- COVID-19

- SARS-CoV-2

- testing

- point of care

- virus are invasive or embarrassing to the infected person. It is observed that salivary glands are hosting severe acute respiratory syndrome-coronavirus-2 (SARS-CoV-2) because of angiotensin-converting enzyme 2 and the detection of high viral loads in the saliva and is playing a crucial role in virus transmission, especially from individuals showing absolutely no symptoms. Saliva is proving to be a promising noninvasive sample specimen for the diagnosis of COVID-19, thus helping to monitor the infection and prevent it from further spreading by prompt isolation.
\end{abstract}

\section{Introduction}

Coronaviruses, hailing from the family of Coronaviridae, nonsegmented positive-sense enveloped RNA viruses, ${ }^{1,2}$ are primarily distributed within humans and other mammals, with a suspected gigantic reservoir of zoonotic origin. ${ }^{1}$ Coronaviruses were not typically associated with being pathogenic in humans in the past. ${ }^{3}$ The two significant outbreaks prior to novel coronavirus disease 2019 (COVID-19) include the severe acute respiratory syndrome-coronavirus-2 (SARS-CoV-2) and Middle East respiratory syndrome-coronavirus (MERS-CoV). Coronaviruses were thought to cause mild, self-limiting

DOI https://doi.org/ $10.1055 / \mathrm{s}-0040-1713020$ ISSN 1305-7456. flu-like respiratory infections in humans before the SARSCoV-2 outbreak in 2003, making it the novel infectious disease of the new century. The ultrastructural morphology of SARS-CoV-2 is illustrated in - Fig. 1 from the Centers for Disease Control and Prevention (CDC) image library. This illustration represents the proteins ( $\mathrm{S}$, spike; E, envelop; and $\mathrm{M}$, membrane) locating on outside surface of virus. It highlights the potential transfer of the virus from animals to humans, proving to be fatal in the process when crossing the species barrier. A suspected large reservoir of SARS-CoV-2 like viruses present in horseshoe bats still appears to be a risk illustrative of a ticking time-bomb, as there is a possibility of humans getting infected, with a resurgence of epic 

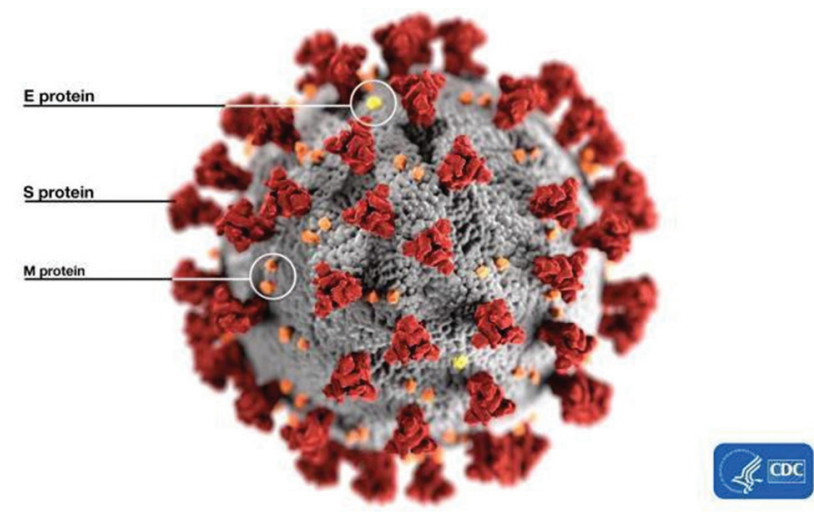

Fig. 1 Illustration representing the ultrastructural morphology of SARSCoV-2 (adapted from CDC Image library: Alissa Eckert, MS; Dan Higgins, MAMS, https://phil.cdc.gov/Details.aspx?pid=23313). E, envelop; M, membrane; S, spike; SARS-CoV-2, severe acute respiratory syndromecoronavirus-2.

proportions. ${ }^{4}$ Almost a decade later in 2012, MERS-CoV was isolated from the sputum of a male patient in Saudi Arabia who had succumbed to acute pneumonia accompanied with renal failure, resulting in an epidemic due to the isolated highly pathogenic coronavirus. This further wreaked another havoc around the world with a MERS-CoV outbreak in South Korea in 2015 due to a person returning from the Middle East to that region. ${ }^{4,5}$ Transmission of SARS-CoV-2 and MERS-CoV occurred mainly due to familial contacts and nosocomial-acquired infections, with the two epidemics causing a cumulative 10,000 cases, with a mortality rate of 10 and $37 \%$, respectively, some even reporting up to $50 \%$ mortality rate for MERS-CoV. ${ }^{1,2,6}$

In December 2019, pneumonia of unknown cause or etiology was reported in the city of Wuhan, Hubei province of China, causing panic and widespread uncertainty in a relatively short period. These initial clusters found in China, as reported by Wu et al, claimed the respiratory illness caused due to SARS-CoV-2, the causative organism for the disease named COVID-19, ${ }^{7}$ was very similar to that caused by SARS-CoV. Affected patients required immediate hospitalization and intensive care, along with a high mortality rate, especially in those presenting with comorbid and old age. ${ }^{1}$ Chinese Center for Disease Control and Prevention (CCDCP), along with the relevant health authorities in China, immediately started to act on isolating and investigating the virus. The viral genome sequence published in data banks, such as Global Initiative on Sharing All Influenza Data (GISAID) and GenBank, on January 11, 2020. ${ }^{8}$ Despite sharing a sequence homology of $80 \%$ with the causative microorganism for the SARS-CoV-2 outbreak, ${ }^{9}$ SARS-CoV-2 exhibits a high level of person-to-person transmission and infectivity. ${ }^{9,10}$

World Health Organization (WHO) labeled the COVID-19 infections emerging in China as a Public Health Emergency of International Concern (PHEIC) on January 30, 2020, further characterizing the disease as a pandemic on March 11,2020 , when cases were increasing tremendously by the hour. ${ }^{11}$ Huang et $\mathrm{al}^{1}$ presented the "epidemiological, clinical, laboratory, and radiological characteristics" in their published article on a total of 41 laboratory-confirmed cases infected with SARS-CoV-2, including a comparison of characteristics between patients admitted to the intensive care unit (ICU), and non-ICU patients. The majority from the sample of infected individuals were males (30/41), 13 of them had underlying health conditions, including hypertension, diabetes, and cardiovascular disease. The most common symptoms reported included fever (40/41), cough (31/41), and myalgia/fatigue/lethargy (18/41). In another retrospective single-center study reported by Chen et al conducted on 99 patients, 82 of the 99 patients had a fever, 81 patients had a cough, 31 had shortness of breath, 11 had myalgia, and 1 patient had nausea and vomiting, among other less common signs and symptoms. ${ }^{12}$ Significant transmission is seen due to family clustering and health care professionals acquiring the disease either from their families or through hospital-acquired infections while coming in contact with other COVID-19 patients, ${ }^{13}$ further enhancing spread with an exponential increase. Majority of the transmissions reported being through direct contact or fomites in the surrounding environment in close quarters with the infected. At the beginning of the epidemic, the initial 138 patients that were hospitalized due to COVID-19 in China, 29\% were health care workers who contracted the disease from proximity to the infected patients. ${ }^{14}$ The virus was isolated on January 7, 2020, commencing the speedy development of diagnostic tests for the disease that was highly sensitive and reliable. The gold-standard test for diagnosing COVID-19 is the real-time reverse transcription quantitative-polymerase chain reaction (RT-qPCR) assay which entails nucleic acid amplification of viral RNA for which a moderately invasive specimen collection is performed. Sample specimens can be collected from the upper respiratory tract in the form of nasopharyngeal or oropharyngeal swabs. They can also be collected from the lower respiratory tract in the form of expectorated sputum, endotracheal aspirate, or bronchoalveolar lavage, specifically for patients presenting with pneumonia. ${ }^{15,16}$ As reported in several articles, the collection of nasopharyngeal and oropharyngeal specimens has resulted in discomfort and bleeding in patients, especially in those with thrombocytopenia. This collection procedure also puts the health care personnel at risk of transmission of the virus during sample collection coming in direct contact with the patients, making it an undesirable method. ${ }^{6,8,17}$ In addition to that, Zheng et al ${ }^{18}$ in their diagnostic validity study demonstrated that nasopharyngeal and oropharyngeal swab detection rates are less as compared with other samples of sputum and saliva. The collection of sputum is a noninvasive specimen, but a relatively less number of patients, around $28 \%$, have reported adequate production of sputum for diagnosis. ${ }^{1}$ Along with the exhaustive process of sample collection and waiting for the results of RT-qPCR, a negative diagnosis still doesn't rule out the possibility of an infection, coupled with the provision of epidemiologic information and travel/contact history. ${ }^{19}$ These tests rendering false-negative results can prove to be of huge risk by letting undiagnosed positive 
cases go by amid a pandemic. 18,20,21 $^{\text {This }}$ was observed in a familial cluster setting as well consisting of a total of six members. The patient-1, who had travelled from epicenter Wuhan back home to Anyang, China, was presumably asymptomatic with her laboratory parameters within normal ranges and her first RT-PCR test negative. But in the process going onward to infect patients-2 to 6 reported in the study which showed symptoms and was hospitalized when their conditions worsened. This proves to be a challenge in containing and mitigating the virus in the light of asymptomatic carriers and lack of mass screening and testing facilities. ${ }^{21}$

Saliva, a noninvasive dynamic biofluid, is currently a biomarker for screening and diagnosing several diseases and conditions because of its ease of access and connection to systemic diseases. ${ }^{22,23}$ Saliva is already being used to diagnose infections of bacterial, viral, or fungal origins, cardiovascular diseases, several types of cancers such as breast and lung cancer, and developmental and genetic diseases. ${ }^{24-26}$ Saliva contains a significant number of biomarkers and components such as RNA and DNA, various immunoglobulins, microorganisms, and metabolites. ${ }^{27}$ Saliva sample collection is also considered to be cheap, easy, and of minimal risk of transmitting the disease to health care personnel as selfcollection involving only the patient is possible. ${ }^{23}$ Human salivary glands are reservoir for the viruses and most likely cell receptor for SARS-CoV-2 investigated in the serological examinations of patient samples concurred to be the angiotensin-converting enzyme 2 (ACE-2) receptor expression. ${ }^{28}$ Hence, those cells expressing ACE- 2 have been intimated of being susceptible to the virus. As the functional receptor for SARS-CoV-2 is the ACE-2 receptor, ${ }^{29}$ significantly lower expression of it has been found in the pharyngeal cells as opposed to salivary glands and the lower respiratory tract. ${ }^{18}$ This makes saliva a relatively better diagnostic specimen for COVID-19 as opposed to pharyngeal specimens. Also, this noninvasive biofluid can be easily collected from the symptomatic and asymptomatic patients without the waste of gloves and personal protection equipments (PPEs). In this pandemic situation, the world is facing shortage of these PPE's due to lockdown protocols.

Developing point-of-care (POC) testing for the diagnoses of COVID-19 remains to be explored and subsequently evaluated for their sensitivity and timely provision of reliable results. POC technology has been defined in the literature as, "medical device used to conduct testing outside the laboratory at or near the site of patient care, including the patient's bedside, the doctor's office, and the patient's home." ${ }^{30}$ Marked infectivity, high pathogenicity, and rapid transmission of COVID-19 have the world on total lockdown with fear and panic in the air. In a time like this, the enforcement of developing POC diagnostics is of utmost importance due to the limited infrastructure and exhausted front liners. It would be able to diagnose cases on site with minimal involvement of already overburdened laboratories, enabling immediate treatment, and prompt containment of the disease during infectious epidemics and pandemics. ${ }^{31,32}$ According to The New York Times, ${ }^{33}$ the health care professionals most liable to contracting COVID-19 from carriers and asymptomatic patients are dentists and associated consultants within the said field because of the proximity to the patients and analogous aerosol-generating procedures being done in the dental clinical setting. ${ }^{19}$ As a considerable viral load was consistently detected in the saliva of patients diagnosed with the infection by up to $91.7 \%,{ }^{6}$ adequate precautionary measures must be taken by dentists, and only emergent dental procedures with the due protocol are performed. ${ }^{34}$ The POC technology, in addition to be an efficient method of diagnosis, also can be made relatively easy to use, if guidelines directed by WHO are followed known as "ASSURED." This abbreviation spells "affordability, sensitivity, specific, user-friendly, robust and rapid, equipment-free, and deliverable to those who need them." 35,36 These guidelines "assure" that the tests being developed thus deliver quick and reliable results, preferably under 30 minutes under resource-constrained settings.

As COVID-19 is mainly spread through droplet infection and contact transmission, potential airborne dissemination has been ruled out except for surroundings where aerosol generation is of concern, including but not limited to endotracheal intubation, bronchoscopy, the patient being disconnected from a ventilator. ${ }^{37-39}$ The use of high-speed handpiece, ultrasonic scaler and instruments, air/water syringe, contaminated surfaces resulting from routine dental procedures, and concomitant aerosolization is of major concern as well. ${ }^{19}$ The difficulty being faced by not being able to diagnose, and effectively asymptomatic quarantine carriers of the infection which may potentially be shedding the virus in their surroundings. So POC diagnostic technology could play a crucial role in this situation. Bringing into context, the use of POC diagnostic technology with saliva to be used as a biomarker for diagnosing COVID-19 in suspected patients seems to be the critical point of demand in health care because of the alarming contagiousness requiring fast diagnostic results. Moreover, the confirmation of significant viral load in the salivary fluid by researchers in Hong Kong ${ }^{6}$ has proven to be a breakthrough in the detection and subsequent diagnosis of SARS-CoV-2 (- Table 1). This proves the potentially budding implementation of widespread salivary point-of-care diagnostics. Added to that, the imminent peril of subsequent spread of the virus through simple acts such as talking, even breathing, to people in the vicinity. ${ }^{28}$ As Azzi et al found in their study ${ }^{9}$ (- Table 1), even after seroconversion of two patients who tested positive for SARS-CoV-2, their salivary specimens still tested positive. This raises concern over discharging patients showing negative pharyngeal respiratory samples but still harboring significant viral loads in their saliva. In turn, proving to be a source of dissemination to their unsuspecting family members and friends. A study reported on detection of salivary pepsin by immunochromatographic strip sensors for the laryngopharyngeal reflux (LPR) patient. ${ }^{26}$ This study revealed the proof of concept for the use of antibody conjugation can help in detection rapidly. There are many other experiments reported for salivary microfluidic paper-based analytical devices ( $\mu$ PAD) for detecting salivary nitrite, glucose, lactate, phosphate, and $\alpha$-amylase. ${ }^{40-43}$ 
Table 1 Description of reported papers on COVID-19 and saliva used as a diagnostic fluid

\begin{tabular}{|c|c|c|c|c|c|c|}
\hline Study & $\begin{array}{l}\text { Document } \\
\text { type }\end{array}$ & $\begin{array}{l}\text { Targeted sam- } \\
\text { ple details }\end{array}$ & $\begin{array}{l}\text { Saliva collection } \\
\text { method }\end{array}$ & $\begin{array}{l}\text { Saliva sample } \\
\text { preparation }\end{array}$ & $\begin{array}{l}\text { Tests } \\
\text { conducted on } \\
\text { saliva }\end{array}$ & Results reported \\
\hline To et $\mathrm{al}^{6}$ & Brief report & $\begin{array}{l}11 \text { patients } \\
\text { (total): } \\
5 \text { females, } \\
7 \text { males. Median } \\
\text { age: } 62.5 \text { years. } \\
\text { Age range: } \\
37-75 \text { years. } \\
12 \text { patients with } \\
\text { laboratory con- } \\
\text { firmed COVID-19 } \\
\text { infection }\end{array}$ & $\begin{array}{l}\text { Self-collection of } \\
\text { saliva. Specimens } \\
\text { collected after } \\
2 \text { days (median) } \\
\text { of hospitali- } \\
\text { zation (range: } \\
0-7 \text { days). } \\
\text { Patient was } \\
\text { asked to cough } \\
\text { the saliva out } \\
\text { which was then } \\
\text { deposited in a } \\
\text { sterile container }\end{array}$ & $\begin{array}{l}2 \mathrm{~mL} \text { of viral } \\
\text { transport } \\
\text { medium } \\
\text { added to the } \\
\text { specimens }\end{array}$ & $\begin{array}{l}\text { Total nucleic } \\
\text { acid extraction. } \\
\text { RT-qPCR. Viral } \\
\text { culture of } \\
\text { SARS-CoV-2 } \\
\text { (level-3 } \\
\text { biosafety } \\
\text { facility) }\end{array}$ & $\begin{array}{l}\text { SARS-CoV-2 ( } 2019 \text {-nCoV) } \\
\text { detected in the initial saliva } \\
\text { samples of } 11 \text { out of the } \\
12 \text { patients ( } 91.7 \% \text { ). Median } \\
\text { viral load in first available } \\
\text { specimens: } 3.3 \times 10^{6} \text { copies/ } \\
\text { mL. Viral load found to be } \\
\text { highest in earliest available } \\
\text { saliva specimens ( } 83.3 \% \text { ). Viral } \\
\text { culture showed the presence of } \\
\text { live virus in saliva of } 3 \text { patients. } \\
1 \text { patient had a slightly higher } \\
\text { viral load in the saliva on day } 1 \\
\text { after being hospitalized than } \\
\text { on the day of hospitalization. } 1 \\
\text { patient found to be shedding } \\
\text { the virus in saliva at day } 11 \\
\text { after hospitalization }\end{array}$ \\
\hline To et $\mathrm{al}^{17}$ & $\begin{array}{l}\text { Observational } \\
\text { cohort study }\end{array}$ & $\begin{array}{l}23 \text { patients } \\
\text { (total): } 13 \text { males, } \\
10 \text { females. } \\
\text { Patients were } \\
\text { laboratory-con- } \\
\text { firmed COVID-19 } \\
\text { affected. } \\
10 \text { patients } \\
\text { suffering from } \\
\text { severe COVID-19 } \\
\text { requiring supple- } \\
\text { mental oxygen. } \\
13 \text { patients had } \\
\text { mild disease. } \\
\text { Median age: } \\
62 \text { years. } \\
\text { Age range: } \\
35-75 \text { years }\end{array}$ & $\begin{array}{l}\text { Patients pro- } \\
\text { duced a saliva } \\
\text { sample by cough- } \\
\text { ing and clearing } \\
\text { the throat early } \\
\text { morning before } \\
\text { breakfast. In } \\
\text { case of intubated } \\
\text { patients, } \\
\text { endotracheal } \\
\text { aspirate was } \\
\text { obtained }\end{array}$ & $\begin{array}{l}\text { Viral transport } \\
\text { medium } \\
\text { added to the } \\
\text { specimens }\end{array}$ & $\begin{array}{l}\text { RT-qPCR which } \\
\text { targeted the } \\
\text { SARS-CoV-2 } \\
\text { RNA- } \\
\text { dependent- } \\
\text { RNA- } \\
\text { polymerase- } \\
\text { helicase gene } \\
\text { region. EIAs for } \\
\text { SARS-CoV-2 } \\
\text { NP and spike } \\
\text { protein RBD }\end{array}$ & $\begin{array}{l}2 \text { patients died. Median viral } \\
\text { load at presentation: } 5.2 \log _{10} \\
\text { copies per mL (IQR: } 4.1-7.0 ; \\
\text { undetectable viral load in } \\
\text { samples given a value of } 1 \log _{10} \\
\text { copies per mL). SAR-CoV-2 } \\
\text { RNA not found in saliva of } 3 \\
\text { patients. Viral load highest in } \\
\text { salivary specimens during first } \\
\text { week of symptom manifesta- } \\
\text { tion. Load gradually declined. } \\
\text { Viral load in endotracheal aspi- } \\
\text { rate highest from day } 8 \text { after } \\
\text { onset of symptoms. Showed } \\
\text { nonsignificant decline. Any } \\
\text { remaining serum was retrieved } \\
\text { for antibody testing from the } \\
\text { blood specimens taken for } \\
\text { biochemical testing. IgG and } \\
\text { IgM antibodies against NP/RBD } \\
\text { increased during first } 10 \text { days } \\
\text { after symptom manifestation }\end{array}$ \\
\hline Chen et al ${ }^{28}$ & $\begin{array}{l}\text { Prospective } \\
\text { study }\end{array}$ & $\begin{array}{l}31 \text { patients } \\
\text { (total): } \\
26 \text { ordinary } \\
\text { or heavy type, } \\
5 \text { on ventilator } \\
\text { support (criti- } \\
\text { cally ill type). } 15 \\
\text { male, } 16 \text { female } \\
\text { patients. Median } \\
\text { age: } 60.6 \text { years. } \\
\text { Age range: } \\
18-86 \text { years }\end{array}$ & $\begin{array}{l}\text { Stimulated } \\
\text { salivary collec- } \\
\text { tion by gentle } \\
\text { massage of } \\
\text { salivary gland. } \\
1.5 \text { mL of } \\
\text { midstream saliva } \\
\text { collected with } \\
\text { cotton swabs } \\
\text { as samples. } \\
\text { Swabs depos- } \\
\text { ited in sterile } \\
\text { dry containers. } \\
\text { Oropharyngeal } \\
\text { swabbing done } \\
\text { as well simul- } \\
\text { taneously with } \\
\text { saliva specimen } \\
\text { collection }\end{array}$ & $\mathrm{N} / \mathrm{A}$ & $\begin{array}{l}\text { Nucleic acid } \\
\text { extraction. } \\
\text { RT-qPCR }\end{array}$ & $\begin{array}{l}13 \text { cases tested positive for } \\
\text { nucleic acid extraction. Out of } \\
\text { the } 13 \text { cases, } 4 \text { tested positive } \\
\text { for nucleic acid extraction of } \\
\text { saliva; } 3 \text { were of critically ill } \\
\text { type with ventilatory support, } \\
1 \text { was of ordinary/heavy type } \\
\text { without ventilatory support }\end{array}$ \\
\hline
\end{tabular}

An observational cohort study conducted in Hong Kong ${ }^{17}$ concluded with findings of high viral loads in posterior oropharyngeal saliva samples in laboratory-confirmed patients of COVID-19 (Table-1). The authors reported that serum immunoglobulin (Ig)-G and IgM antibodies were detected after 10 or more days from symptom manifestation and 
Table 1 (continue)

\begin{tabular}{|c|c|c|c|c|c|c|}
\hline Study & $\begin{array}{l}\text { Document } \\
\text { type }\end{array}$ & $\begin{array}{l}\text { Targeted sam- } \\
\text { ple details }\end{array}$ & $\begin{array}{l}\text { Saliva collection } \\
\text { method }\end{array}$ & $\begin{array}{l}\text { Saliva sample } \\
\text { preparation }\end{array}$ & $\begin{array}{l}\text { Tests } \\
\text { conducted on } \\
\text { saliva }\end{array}$ & Results reported \\
\hline Zheng et al ${ }^{18}$ & $\begin{array}{l}\text { Prospective } \\
\text { diagnostic } \\
\text { validity study }\end{array}$ & $\begin{array}{l}65 \text { patients } \\
\text { (total): } 40 \text { males, } \\
25 \text { females. } \\
23 \text { patients with } \\
\text { mild disease, } \\
42 \text { patients with } \\
\text { severe disease. } \\
8 \text { patients } \\
\text { admitted in } \\
\text { ICU, } 2 \text { received } \\
\text { mechanical } \\
\text { ventilation. } \\
\text { Patients were } \\
\text { laboratory-con- } \\
\text { firmed COVID-19 } \\
\text { affected. } \\
\text { Median age: } \\
54 \text { years. IQR: } \\
\text { 39.5-62 years }\end{array}$ & $\begin{array}{l}\text { Patients pro- } \\
\text { duced saliva by } \\
\text { coughing three } \\
\text { to five times } \\
\text { (wearing a mask) } \\
\text { and spitting } \\
\text { into a sterile } \\
\text { container }\end{array}$ & $\mathrm{N} / \mathrm{A}$ & $\begin{array}{l}\text { Extraction of } \\
\text { viral RNAs, } \\
\text { RT-qPCR }\end{array}$ & $\begin{array}{l}37 \text { out of } 42(88.09 \%) \text { salivary } \\
\text { samples detected SARS- } \\
\text { CoV-2 as compared with } \\
\text { the detection rates of throat } \\
\text { swabs }(45.24 \%, 19 / 24) \text {, and } \\
\text { nasal swabs }(76.19 \%, 32 / 42) \text {. } \\
\text { Significantly higher viral loads } \\
\text { were detected in saliva samples } \\
\text { as compared with throat swabs }\end{array}$ \\
\hline Azzi et al $^{9}$ & Research article & $\begin{array}{l}25 \text { patients: } \\
17 \text { males, } 8 \\
\text { females. Average } \\
\text { age: } 61.5 \pm \\
11.2 \text { years. } \\
\text { Age range: } \\
\text { 39-85 years. } \\
\text { Laboratory con- } \\
\text { firmed COVID-19 } \\
\text { patients with } \\
\text { severe/very } \\
\text { severe disease } \\
\text { were included }\end{array}$ & $\begin{array}{l}\text { Drooling tech- } \\
\text { nique used for } \\
\text { saliva collec- } \\
\text { tion. In case of } \\
\text { patients with } \\
\text { endotracheal } \\
\text { intubation or } \\
\text { on mechanical } \\
\text { ventilators, saliva } \\
\text { was collected } \\
\text { by healthcare } \\
\text { professionals } \\
\text { with the use of } \\
\text { pipettes }\end{array}$ & $\begin{array}{l}\text { Saliva } \\
\text { suspended in } \\
2 \mathrm{~mL} \text { PBS }\end{array}$ & $\begin{array}{l}\text { Nucleic acid } \\
\text { extraction, } \\
\text { RT-qPCR }\end{array}$ & $\begin{array}{l}\text { SARS-CoV-2 detected in all } \\
25 \text { patients' first salivary } \\
\text { sample. Second salivary swab } \\
\text { after } 4 \text { days duration on } 8 \\
\text { patients yielded consistent } \\
\text { results with first saliva inves- } \\
\text { tigation. } 2 \text { patients exhibited } \\
\text { positive salivary diagnosis even } \\
\text { when their pharyngeal + bron- } \\
\text { choalveolar samples tested } \\
\text { negative }\end{array}$ \\
\hline
\end{tabular}

Abbreviations: COVID-19, novel coronavirus disease 2019; EIA, enzyme immunoassays; ICU, intensive care unit; Ig, immunoglobulin; IQR, interquartile range; N/A, not available; NP, nucleoprotein; RBD, receptor binding domain; $\mathrm{RT}$-qPCR, real-time reverse transcription-quantitative polymerase chain reaction; SARS-CoV-2, severe acute respiratory syndrome-coronavirus-2.

viral RNA was still evident in saliva samples. This is of major concern in those displaying almost mild to no symptoms at all and still can be spreading the virus at an alarming rate. ${ }^{17}$ Not only is saliva proving to be a dynamic biofluid to diagnose COVID-19, but also is substantive in providing information on the course of the infectious disease. ${ }^{9}$ The expression of ACE-2 is relatively higher in the salivary glands when compared with that of lungs, ${ }^{44,45}$ ascertaining that COVID-19 could potentially target these glands, with saliva exhibiting viral RNA even before lung injury manifests. ${ }^{46}$

Notwithstanding the limitations in the studies being conducted in uncertain times like these in the midst of the ongoing pandemic. Recently, Ahmed et al reported anxiety and fear among dentists around the world due to COVID-19 pandemic outbreak. ${ }^{47}$ They concluded that majority of the dentist have either modified or limited their practices to emergency treatment only, while others have closed their practices until life get back to normal. As already understood, COVID-19 is an emerging novel infection with something new to learn with every passing day. Saliva is looking to be a promising biofluid for the effective diagnosis of COVID-19, but further studies need to be conducted on asymptomatic individuals to understand the disease process better. ${ }^{28}$ As many studies are being held on patients presenting at hospitals for intensive care with severe disease, high viral loads are understandably being found. ${ }^{6,17,28}$ As opposed to that, community-wise detection of saliva in patients with mild infections not requiring hospitalization needs to be conducted. ${ }^{18}$ Recently, Rutgers Clinical Genomic Laboratory in the United States got approval from the Food and Drug Administration (FDA) for testing human saliva, as the primary test biomaterial for the SARS-CoV-2 coronavirus. According to Prof. Andrew Brooks, "The impact of this approval is significant." Prof. Brooks is currently leading this project with other collaborators. ${ }^{40}$ 


\section{Conclusion and Future Remarks}

As demonstrated by studies reviewed in this article, high viral loads of SARS-CoV-2 RNA are being found in salivary gland and saliva, potentially illustrating the importance of this biofluid for testing the disease in asymptomatic condition. It is of utmost importance that in the current situation of the pandemic and astonishing transmissibility of the virus, a mass screening tool be developed using saliva POC technology. POC technology using saliva as a form of liquid biopsy for diagnosing COVID-19 patients on the spot can be a pivotal turning point in rapid detection. This would effectively help in identifying and isolating potential carriers and contacts in hopes of containing and mitigating the disease.

\section{Conflict of Interest}

None declared.

\section{References}

1 Huang C, Wang Y, Li X, et al. Clinical features of patients infected with 2019 novel coronavirus in Wuhan, China. Lancet 2020;395(10223):497-506

2 Fehr AR, Perlman S, Coronaviruses: an overview of their replication and pathogenesis. In: Maier HJ, Bickerton E, Britton P, eds. Coronaviruses: Methods and Protocols. Vol. 1282. New York, NY: Springer; 2015:1-23

3 Kim YI, Kim SG, Kim SM, et al. Infection and rapid transmission of SARS-CoV-2 in ferrets. Cell Host Microbe 2020;27(5): 704-709.e2 doi:10.1016/j.chom.2020.03.023

4 Yin Y, Wunderink RG. MERS, SARS and other coronaviruses as causes of pneumonia. Respirology 2018;23(2):130-137

5 Zaki AM, van Boheemen S, Bestebroer TM, Osterhaus ADME, Fouchier RAM. Isolation of a novel coronavirus from a man with pneumonia in Saudi Arabia. N Engl J Med 2012;367(19):1814-1820

6 To KK, Tsang OT, Chik-Yan Yip C, et al. Consistent detection of 2019 novel coronavirus in saliva. Clin Infect Dis 2020;4-6:ciaa149

7 Wu Y, Ho W, Huang Y, et al. SARS-CoV-2 is an appropriate name for the new coronavirus. Lancet 2020;395(10228):949-950

8 Khurshid Z, Asiri FYI, Al Wadaani H. Human saliva: non-invasive fluid for detecting novel coronavirus (2019-nCoV) Int J Environ Res Public Health 2020;17(7):22-25

9 Azzi L, Carcano G, Gianfagna F, et al. Saliva is a reliable tool to detect SARS-CoV-2. J Infect 2020;81(1):e45-e50 doi:10.1016/j. jinf.2020.04.005

10 Xu R, Cui B, Duan X, Zhang P, Zhou X, Yuan Q. Saliva: potential diagnostic value and transmission of 2019-nCoV. Int J Oral Sci 2020;12(1):11

11 Sohrabi C, Alsafi Z, O'Neill N, et al. World Health Organization declares global emergency: a review of the 2019 novel coronavirus (COVID-19) Int J Surg 2020;76:71-76

12 Chen N, Zhou M, Dong X, et al. Epidemiological and clinical characteristics of 99 cases of 2019 novel coronavirus pneumonia in Wuhan, China: a descriptive study. Lancet 2020;395(10223):507-513

13 Thomas-Rüddel D, Winning J, Dickmann P, et al. Coronavirus disease 2019 (COVID-19): Update for anesthesiologists and intensivists March 2020 [published online ahead of print, 2020 Mar 24]. Anaesthesist 2020;1-10 doi:10.1007/s00101020-00760-3

14 Wang D, Hu B, Hu C, et al. Clinical characteristics of 138 hospitalized patients with 2019 novel coronavirus-infected pneumonia in Wuhan, China. JAMA 2020;323(11): 1061-1069

15 Patel R, Babady E, Theel ES, et al. Report from the American Society for Microbiology COVID-19 International Summit, 23 March 2020: value of diagnostic testing for SARS-CoV-2/ COVID-19. MBio 2020;11(2):e00722-20

16 Report of the WHO-China Joint Mission on Coronavirus Disease. 2019 (COVID-19). Available at: https://www.who.int/ docs/default-source/coronaviruse/who-china-joint-missionon-covid-19-final-report.pdf. Accessed May 8, 2020

17 To KK, Tsang OT, Leung WS, et al. Temporal profiles of viral load in posterior oropharyngeal saliva samples and serum antibody responses during infection by SARS-CoV-2: an observational cohort study. Lancet Infect Dis 2020;20(5):565-574

18 Zheng S, Yu F, Fan J, et al. Saliva as a diagnostic specimen for SARS-CoV-2 by a PCR-based assay: a diagnostic validity study. Clin Microbiol Infect 2020;25(3):372-378

19 Meng L, Hua F, Bian Z. Coronavirus disease 2019 (COVID-19): emerging and future challenges for dental and oral medicine. J Dent Res 2020;99(5):481-487

20 Winichakoon P, Chaiwarith R, Liwsrisakun C, et al. Negative Nasopharyngeal and Oropharyngeal Swab Does Not Rule Out COVID-19 2 Downloaded from. J Clin Microbiol 2020;58(5):e00297-e007320

21 Bai Y, Yao L, Wei T, et al. Presumed asymptomatic carrier transmission of COVID-19. JAMA 2020;323(14):1406-1407

22 Khurshid Z, Zafar M, Khan E, Mali M, Latif M. Human saliva can be a diagnostic tool for Zika virus detection. J Infect Public Health 2019;12(5):601-604

23 Khurshid Z, Zohaib S, Najeeb S, Zafar MS, Slowey PD, Almas K. Human saliva collection devices for proteomics: an update. Int J Mol Sci 2016;17(6):846

24 Khurshid Z, Zafar MS, Khan RS, Najeeb S, Slowey PD, Rehman IU. Role of salivary biomarkers in oral cancer detection. Adv Clin Chem 2018;86:23-70

25 Sahibzada HA, Khurshid Z, Khan RS, et al. Salivary IL-8, IL-6 and TNF- $\alpha$ as potential diagnostic biomarkers for oral cancer. Diagnostics (Basel) 2017;7(2):21

26 Abdul Rehman S, Khurshid Z, Hussain Niazi F, et al. Role of salivary biomarkers in detection of cardiovascular diseases (CVD) Proteomes 2017;5(3):21

27 Khurshid Z, Moin SF, Khan RS, Agwan MAS, Alwadaani AH, Zafar MS. Human salivary protein extraction from RNAPro.SAL ${ }^{\mathrm{TM}}$, Pure.SAL ${ }^{\mathrm{TM}}$, and passive drooling method. Eur J Dent 2017;11(3):385-389

28 Chen L, Zhao J, Peng J, et al. Detection of SARS-CoV-2 in saliva and characterization of oral symptoms in COVID-19 patients. Cell Prolif 2020;53(12):e12923 doi:10.1111/cpr.12923

29 Hamming I, Timens W, Bulthuis ML. Lely AT, Navis G, van Goor $\mathrm{H}$. Tissue distribution of ACE2 protein, the functional receptor for SARS coronavirus. A first step in understanding SARS pathogenesis. J Pathol 2004;203(2):631-637

30 Khurshid Z. Salivary point-of-care technology. Eur J Dent 2018;12(1):1-2 doi:10.4103/ejd.ejd_376_17

31 Loeffelholz MJ, Tang YW. Laboratory diagnosis of emerging human coronavirus infections - the state of the art. Emerg Microbes Infect 2020;9(1):747-756 doi:10.1080/22221751.20 20.1745095

32 Kozel TR, Burnham-Marusich AR. Point-of-care testing for infectious diseases: Past, present, and future. J Clin Microbiol 2017;55(8):2313-2320

33 Gamio L; The New York Times. The Workers Who Face the Greatest Coronavirus Risk. Available at: https://www.nytimes. com/interactive/2020/03/15/business/economy/coronavirus-worker-risk.html. Accessed May 8, 2020

34 Bonebreak CM, Demirci U, Kuo WP. The potential of salivary point of care diagnostics. J Appl Oral Sci 2011;19(4) 
35 LaBarre P, Boyle D, Hawkins K, Weigl B, Instrument-free nucleic acid amplification assays for global health settings. In: Kumar BVKV, Prabhakar S, Ross AA, et al, eds. Sensing Technologies for Global Health, Military Medicine, Disaster Response, and Environmental Monitoring; and Biometric Technology for Human Identification VIII. Vol 8029. Bellingham, WA: SPIE; 2011802902

36 Kosack CS, Page AL, Klatser PR. A guide to aid the selection of diagnostic tests. Bull World Health Organ 2017;95(9):639-645

37 Guo ZD, Wang ZY, Zhang SF, et al. Aerosol and surface distribution of severe acute respiratory syndrome coronavirus 2 in hospital wards, Wuhan, China, 2020. Emerg Infect Dis 2020;26(7):1583-1591 doi:10.3201/eid2607.200885

38 Gan WH, Lim JW, Koh D. Preventing intra-hospital infection and transmission of coronavirus disease 2019 in health-care workers. Saf Health Work 2020;11(2):241-243 doi:10.1016/j. shaw.2020.03.001

39 Black JRM, Bailey C, Przewrocka J, Dijkstra KK, Swanton C. COVID-19: the case for health-care worker screening to prevent hospital transmission. Lancet 2020;395(10234):1418-1420

40 Malon RS, Sadir S, Balakrishnan M, Córcoles EP. Saliva-based biosensors: noninvasive monitoring tool for clinical diagnostics. BioMed Res Int 2014;2014:962903

41 Bhakta SA, Borba R, Taba M Jr., Garcia CD, Carrilho E. Determination of nitrite in saliva using microfluidic paperbased analytical devices. Anal Chim Acta 2014;809:117-122
42 de Castro LF, de Freitas SV, Duarte LC, de Souza JAC, Paixão TRLC, Coltro WKT. Salivary diagnostics on paper microfluidic devices and their use as wearable sensors for glucose monitoring. Anal Bioanal Chem 2019;411(19):4919-4928

43 Campuzano S, Yánez-Sedeño P, Pingarrón JM. Electrochemical bioaffinity sensors for salivary biomarkers detection. TrAC Trends in Analytical Chemistry 2017;86:14-24 doi:10.1016/j. trac.2016.10.002

44 Xu J, Li Y, Gan F, Du Y, Yao Y. Salivary Glands: Potential Reservoirs for COVID-19 Asymptomatic Infection. J Dent Res 2020;99(8):989 doi:10.1177/0022034520918518

45 Liu L, Wei Q, Alvarez X, et al. Epithelial cells lining salivary gland ducts are early target cells of severe acute respiratory syndrome coronavirus infection in the upper respiratory tracts of rhesus macaques. J Virol 2011;85(8):4025-4030

46 Wang WK, Chen SY, Liu IJ, et al. Detection of SARS-associated coronavirus in throat wash and saliva in early diagnosis. Emerg Infect Dis 2004;10(7):1213-1219 doi:10.3201/ eid1007.031113

47 Ahmed MA, Jouhar R, Ahmed N, et al. Fear and practice modifications among dentists to combat novel coronavirus disease (COVID-19) outbreak. Int J Environ Res Public Health 2020;17(8):2821 doi:10.3390/ijerph17082821 